\title{
The Scramble for Africa Reloaded? Portugal, European Colonial Claims and the Distribution of Colonies in the 1930s
}

\author{
Márcia Gonçalves (D) \\ Institute of Contemporary History - NOVA FCSH, Av. Berna, 26 C 1069-061 Lisbon, Portugal \\ marcia.goncalves@eui.eu
}

\begin{abstract}
Situating itself at the crossroads of colonial history, international history and European history, this article examines the movement for colonial appeasement and the redistribution of African colonies in the 1930s from a frequently overlooked viewpoint: Portugal and its empire. Even though Portugal was not a principal actor in the discussion of colonial redistribution, the Portuguese empire was placed at the centre of these debates as a subject to be discussed. The article demonstrates that the great powers' perception of Portugal as an inadequate colonial power was central to their strategy of colonial redistribution in an international context that espoused guarantees of territorial integrity to great and small states alike. In addition, it shows how Portugal entered the debate on colonial appeasement to promote a rhetoric of victimisation and bolster support for the dictatorship.
\end{abstract}

On 29 January 1937 the head of the Portuguese government, António de Oliveira Salazar, released a long official note to the press. Salazar aimed to put an end to the 'expansion of fake news' in the foreign press. ${ }^{1}$ The previous month, both the Swiss New Basel Newspaper (Neue Basler Zeitung) and the French The Times (Le Temps) had informed their readers that Portugal was negotiating the handover of Angola to Germany. ${ }^{2}$ Portuguese diplomats had quickly refuted the claims. ${ }^{3}$ Nevertheless, rumours persisted and grew in detail in the following weeks. By the time Salazar's note appeared in the press it had been reported that Portugal would lease Angola to a German chartered company for ninety-nine years, keeping only nominal sovereignty over the colony. The Portuguese dictator had an emphatic message for 'those who attack us and raise rumours about our colonies': 'we will not sell, we will not lease, we will not lend, we will not share our colonies. . . . Our constitutional laws do not allow it; and, if these laws did not exist, our national consciousness would not allow it. ${ }^{4}$

Rumours involving an upcoming sale or lease of one or more Portuguese colonies had been appearing in European, American and South African newspapers since the early 1930s and would continue to emerge until the outbreak of the Second World War. Along with the erosion of democratic institutions, the radicalisation of expansionist discourses in authoritarian regimes and the collapse of international disarmament efforts, the 1930s witnessed growing demands for a redistribution of colonial territory. The impact of the Wall Street Crash of 1929 precipitated a severe worldwide economic

\footnotetext{
1 Reprinted as António de Oliveira Salazar, 'O Suposto Arrendamento de Angola à Alemanha', in Discursos e Notas Políticas. II. 1935-1937 (Coimbra: Coimbra Editora, 1945), 263.

2 Neue Basler Zeitung, 8 Dec. 1936, and Le Temps, 15 Dec. 1936, 6.

3 Veiga Simões to Salazar, 10 Dec. 1936, in Arquivo Nacional Torre do Tombo (ANTT), Lisbon, AOS/CO/UL-12, cx. 805, pt. 1-12, and Teixeira de Sampaio to Ministry of the Colonies, 21 Jan. 1937 in Arquivo Histórico Ultramarino (AHU), Lisbon, MU/1H/996, proc. 16/1.

4 Salazar, 'O Suposto Arrendamento', 264.

(c) The Author(s), 2020. Published by Cambridge University Press
} 
depression. As European colonial powers turned to their empires to facilitate their reconstruction and rebalance metropolitan budgets, the glaring distinction between countries with colonies and those without put an additional strain on international relations. In a geopolitical scene dominated by great European powers and the rivalries between them, Portugal remained a peripheral country, small in both size and importance. Yet, in the early 1930s Portugal had the world's third largest colonial empire, behind only the United Kingdom and France, occupying a significant area of Africa in addition to some smaller colonies in Asia.

As European rivalries grew more intense, the idea that the scramble for Africa had not come to an end with the First World War began to take shape in Portugal. In this article I explore how the rumours about the Portuguese empire related to wider debates on the redistribution of colonial resources and plans for colonial appeasement. British and French strategies of seeking out diplomatic compromises and concessions to avoid resorting to an armed conflict with Germany during the 1930s have attracted a great deal of attention on the part of historians and political scientists alike. ${ }^{5}$ However, colonial appeasement has not been a central topic in this discussion. Wm. Roger Louis and Andrew Crozier are the exceptions, but their investigations are centred on the British perspective and both analyses are built on exclusively British sources. ${ }^{6}$ Their approaches offer an invaluable understanding of the diplomatic traces of colonial appeasement, but they say little about the reception and impact of colonial appeasement beyond the circles of high diplomacy. Recently Susan Pedersen has explored the extraordinary level of public attention that colonial appeasement attracted at the time in her study of the League of Nations' Permanent Mandates Commission. Pedersen shows how British and French statesmen's plans to offer Hitler a colony in Africa contributed to the failure of the interwar internationalist project on which the League was based by discrediting it in the eyes of the European liberal elites. ${ }^{7}$ This article aims to complement these approaches by shifting the focus away from the great European powers and the internationalist movement; instead, it will look at colonial appeasement and redistribution of colonial resources from a marginal viewpoint.

The point of departure of my analysis is Portugal and the Portuguese empire. Situating itself at the crossroads of colonial history, international history and European history, this article will show how the European crisis of the 1930s that culminated in the outbreak of the Second World War cannot be fully understood without paying attention to its entanglement with imperial order. I will begin by briefly introducing the international framework of the renewed interest in African partitioning, placing it within the wider context of inter-European rivalries and internationalisation of imperial debates before the Second World War. Then, I will demonstrate that, even though Portugal was not a principal actor in the discussion of colonial redistribution, the Portuguese Empire was placed at the centre of these debates as a subject to be discussed. Finally, I will turn to the Portuguese response to rumours about colonial appeasement projects to show how they were exploited for nationalistic purposes in Portugal.

\footnotetext{
5 There exists today a voluminous body of literature on appeasement which is not possible to cover here. For a critical overview on the historiography of appeasement written during the twentieth century, see Patrick Finney, 'The Romance of Decline: The Historiography of Appeasement and British National Identity', Electronic Journal of International History, 1 (2000). Appeasement remains a subject of interest in the twenty-first century. Among the titles produced after 2000, see, for instance, Peter Neville, Hitler and Appeasement: The British Attempt to Prevent the Second World War (New York: Hambledon Continuum, 2005); James P. Levy, Appeasement and Rearmament: Britain, 1936-1939 (Lanham, MD: Rowman \& Littlefield, 2006); Sidney Aster, 'Appeasement: Before and After Revisionism', Diplomacy \& Statecraft, 19, 3 (2008), 443-80; Martin Thomas, 'Appeasement in the Late Third Republic', Diplomacy \& Statecraft, 19, 3 (2008), 566-607; Tim Bouverie, Appeasing Hitler: Chamberlain, Churchill and the Road to War (London: Bodley Head, 2019).

6 Wm. Roger Louis, 'Colonial Appeasement, 1936-1938', Revue Belge de Philologie et d'histoire, 49, 4 (1971), 1175-91; Andrew J. Crozier, Appeasement and Germany's Last Bid for Colonies (London: Macmillan Press, 1988).

7 Susan Pedersen, The Guardians: The League of Nations and the Crisis of Empire (Oxford: Oxford University Press, 2015), $325-55$.
} 


\section{'Everybody Wants Colonies'}

On 21 December 1938 the leading article of the well-known and widely circulated Portuguese newspaper Daily News (Diário de Notícias) carried the provocative title 'Everybody Wants Colonies'. It was a harsh criticism of countries that were - in the author's words - 'hungry for colonies': Mussolini had taken over Ethiopia by force, the question of the restitution of former German colonies had moved on considerably and, it was argued, everybody felt entitled to become a colonial power. ${ }^{8}$

The Italian invasion of Ethiopia had taken place in October 1935. Italian colonial ambitions had been revived during the First World War. Italy's entry into the war on the side of the Entente powers had been negotiated in 1915 on extremely advantageous terms for the Italians. Anticipating the disintegration of the Austro-Hungarian and Ottoman empires, it was agreed that Italy would obtain Trentino-South Tyrol, as well as territories on the shores of the Adriatic Sea and the Turkish Mediterranean coast. The 1915 Treaty of London further stated that, should France and the United Kingdom increase their colonial territories in Africa at the expense of Germany, Italy could claim some equitable compensation. ${ }^{9}$ However, the negotiations at the Paris Peace Conference in 1919 fell short of delivering the Italians' expected result. The US president Woodrow Wilson made clear that his country was not bound by secret agreements and that Italian claims violated his guiding principle of self-determination. ${ }^{10}$ In the end Italy received Trentino-South Tyrol and a share of the German reparations, but the plan to expand Italy's territory along the Adriatic coast never came to fruition and their aspirations in Africa were dashed. The idea of 'mutilated victory' (vittoria mutilata) gained momentum: Italy had not only been humiliated by its allies but also deprived of important economic resources and confined to a small territory that was insufficient for its growing population. ${ }^{11}$ Capitalising on the widespread popular disappointment, Mussolini rose to power in 1922 with a promise to restore Italy's former might and the glory of the Roman Empire. ${ }^{12}$

In the face of strong resistance to their claims in the Adriatic, Italian delegates did not push their African interests at the Paris Peace Conference, even though Germany was forced to renounce all its rights to its colonies and France and the United Kingdom were the greatest beneficiaries. In accordance with President Wilson's envisioned anti-annexationist peace, the former colonies were transformed into mandates of the League of Nations and placed under the administration of the Allied powers; however, these territories were not to be annexed nor be seen as spoils of war. ${ }^{13}$ Their transfer

8 Diário de Notícias, 21 Dec. 1938, 1.

9 Agreement between France, Russia, Great Britain and Italy, Signed at London, April 26, 1915 (London: H.M. Stationery Office, 1920), 3-6.

10 Margaret MacMillan, Paris 1919: Six Months That Changed the World (New York: Random House, 2003), $279-91$.

11 H. James Burgwyn, The Legend of the Mutilated Victory: Italy, the Great War, and the Paris Peace Conference, 1915-1919 (Westport, CT: Praeger, 1993); Giulia Albanese, 'Versailles/Versaglia: La "Vittoria Mutilata"', in Mario Isnenghi and Daniele Ceschin, eds., Gli Italiani in Guerra. Conflitti, Identità, Memorie Dal Risorgimento Ai Nostri Giorni, Vol. 3, La Grande Guerra. Dall'intervento Alla "Vittoria Mutilata" (Turin: Utet, 2009), 735-42.

12 On the importance of colonial imperialism in redefining the fascist regime in the 1930s, see Alexander De Grand, 'Mussolini's Follies: Fascism in Its Imperial and Racist Phase, 1935-1940', Contemporary European History, 13, 2 (2004), 127-47. See also Esmonde M. Robertson, Mussolini As Empire Builder: Europe and Africa, 1932-36 (London: Macmillan, 1977); Nicola Labanca, Oltremare: storia dell'espansione coloniale italiana (Bologna: Il Mulino, 2002); Nicola Labanca, 'Studies and Research on Fascist Colonialism, 1922-1935: Reflections on the State of Art', in Patrizia Palumbo, ed., A Place in the Sun: Africa in Italian Colonial Culture from Post-Unification to the Present (Berkeley: University of California Press, 2003), 37-61.

13 'If any nation could annex territory which was previously a German Colony, it would be challenging the whole idea of the League of Nations', Wilson argued during the Supreme Council of the Peace Conference's meeting held in the afternoon of 27 January 1919, in Papers Relating to The Foreign Relation Of The United States: The Paris Peace Conference 1919. Volume III (Washington, DC: United States Government Printing Office, 1943), 742. On the League's Mandatory system, see Michael D. Callahan, Mandates and Empire: The League of Nations and Africa, 1914-1931 (Brighton: Sussex Academic Press, 1999); Michael D. Callahan, A Sacred Trust: The League of Nations and Africa, 1929-1946 (Brighton: Sussex Academic Press, 2004); Michael D. Callahan, “Mandated Territories Are Not Colonies": Britain, France, and Africa in the 1930s', in R. M. Douglas, Michael D. Callahan and Elizabeth Bishop, eds., Imperialism on Trial: International Oversight of Colonial Rule in Historical Perspective (Lanham, MD: Lexington Books, 2006), 1-20; Susan 
of power from Germany to the League of Nations was not justified on the grounds of Germany's defeat but rather on the basis that the Germans had proven unfit to colonise due to their brutality as a colonial power. Materials gathered by the British authorities in South West Africa were essential to build the case against German colonialism during the peace negotiations. ${ }^{14}$ Contesting the idea of German unfitness - which the last governor of German East Africa, Heinrich Schnee, later dubbed the 'colonial guilt lie' (Koloniale Schuldlüge) - was at the heart of the emergent colonial revisionist movement. ${ }^{15}$ Despite not being a movement with a widespread popular base, advocates for the return of the overseas colonies could be found across most political parties represented in parliament in the Weimar Republic and many joined the Nazi Party in the 1930s. ${ }^{16}$ Even though the reclamation of former Prussian and Habsburg territories in Europe was prioritised, colonial claims were not forgotten after 1933. After his rise to power Hitler was reported to have announced that 'as for our colonies overseas, we have certainly not renounced our colonial aspirations: there is a large quantity of products which Germany must get from the tropics, and we need colonies just as badly as any other Power. ${ }^{17}$ After the remilitarisation of the Rhineland in 1936 public pronouncements on colonial restitution were reiterated and German colonialist organisations were absorbed into the renewed Nazi Party's Reich Colonial League (Reichskolonialbund). ${ }^{18}$ As its leader, Franz Ritter von Epp, summed up when asked for an authoritative statement of the German point of view regarding the 'colonial problem', 'the demand for the return of former colonial territories is a matter of right' and 'Germany's juridical and moral demands for colonial justice' ought to be satisfied. ${ }^{19}$

The legal and moral grounds for the restitution of former colonies invoked by German colonial revisionists were not met with hostility in Portugal. The mocking tone in Diário de Notícias's criticism of 'colonial entitlement' was directed at a different target: Poland. In September 1936 the Polish minister of Foreign Affairs, Colonel Józef Beck, pleaded to the assembly of the League of Nations for an international solution for his country's lack of access to raw materials and its overpopulation. The Polish representatives also requested membership to the League's Permanent Mandates Commission, which supervised the mandatory powers' administration in the mandated territories. Even though Colonel Beck would later argue that the intention was not to involve Poland in 'the dangerous game of colonial ambitions, ${ }^{20}$ the lobby for Poland's colonial expansion was very active during the interwar period. ${ }^{21}$ Like Italy and Germany, Poland adopted the language of scarcity of raw

Pedersen, 'The Meaning of the Mandates System: An Argument', Geschichte Und Gesellschaft, 32, 4 (2006), 560-82; Pedersen, Guardians.

14 Report on the Natives of South-West Africa and Their Treatment by Germany (London: H. M. Stationery Office, 1918). For a critical reading of the 1918 Blue Book, see Christina Twomey, 'Atrocity Narratives and Imperial Rivalry: Britain, Germany and the Treatment of "Native Races”, 1904-1939', in T. Crook, R. Gill, and B. Taithe, eds., Evil, Barbarism and Empire: Britain and Abroad, c.1830-2000 (London: Palgrave Macmillan, 2011), 201-25.

15 Heinrich Schnee, 'Die Koloniale Schuldlüge', Süddeutsche Monatshefte, 21, 4 (1924), 91-152; Sean Wempe, Revenants of the German Empire: Colonial Germans, Imperialism, and the League of Nations (Oxford: Oxford University Press, 2019), 31-67.

16 Wolfe W. Schmokel, Dream of Empire: German Colonialism, 1919-1945 (New Haven: Yale University Press, 1964), 1-14; Klaus Hildebrand, Vom Reich Zum Weltreich: Hitler, NSDAP U. Koloniale Frage 1919-1945 (München: Wilhelm Fink Verlag, 1969), 56-62; Woodruff D. Smith, The German Colonial Empire (Chapel Hill, NC: University of North Carolina Press, 1978), 53-4; Lora Wildenthal, German Women for Empire, 1884-1945 (Durham, NC: Duke University Press, 2001), 182; Shelley Baranowski, Nazi Empire: German Colonialism and Imperialism from Bismarck to Hitler (Cambridge: Cambridge University Press, 2011), 148-55; Wempe, Revenants, 218-9.

17 Quoted in Germany's Claim to Colonies (London: The Royal Institute of International Affairs, 1938), 26.

18 On the Nazification of German colonial propaganda, see Schmokel, Dream of Empire, 20-45; Wildenthal, German Women, 185; Karsten Linne, Deutschland jenseits des Äquators?: Die NS-Kolonialplanungen für Afrika (Berlin: Ch. Links Verlag, 2008), 26-42; Wempe, Revenants, 126-7.

19 Ritter von Epp, 'The Question of Colonies: The German Standpoint', Journal of the Royal African Society, 36, 142 (1937), 6, 8. Originally published in German in Europäische Revue (Sept. 1936).

20 Józef Beck, Final Report (New York: R. Speller, 1957), 132-3.

21 Poland's colonial ambitions were not new though. Lenny Ureña Valerio has shown that they predated the existence of Poland as an independent state. Lenny Ureña Valerio, 'The Stakes of Empire: Colonial Fantasies, Civilizing Agendas, and Biopolitics 
materials and population pressures when attempting to justify the need for territorial expansion. Unlike the future Axis powers, Poland looked for a solution within the League of Nations. But Polish colonial claims were looked upon with apprehension in Portugal. It was feared that, by disguising its colonial claims as 'claims for territories rich in raw materials in which to place their surplus agricultural population', Poland was 'dangerously magnifying the issue': the appropriation of the language of internationalism made these claims acceptable and could revive the discussion of the problem of colonial raw materials in the 'Great Hall of Geneva'.

\section{The Problem of Raw Materials}

By the time Italian troops were amassing at the Ethiopian border, British Foreign Minister Samuel Hoare began to suggest that the assembly of the League of Nations launch an enquiry into the problem of colonial raw materials. His government, he said, was convinced that the problem of colonial demands was 'economic rather than political and territorial', being motivated by the fear of exclusion or monopoly in the access to essential colonial raw materials. Therefore, it was necessary to ensure the fair distribution of such resources in order to prevent war. ${ }^{23}$ A resolution to create a committee to study 'the question of equal commercial access for all nations to certain raw materials' was adopted in $1936 .{ }^{24}$ As has been noted, the stress on 'commercial access' excluded any consideration of territorial claims. ${ }^{25}$ Yet, for the Portuguese government the League of Nations was already going too far.

During his intervention at the annual meeting of the League's assembly in 1936 the Portuguese minister of Foreign Affairs, Armindo Monteiro, insisted that believing European economic pressures could be solved through international agreements to facilitate the access of colonial raw materials was an illusion. Emphasising that Portugal had five centuries of colonial experience, Monteiro claimed that he could attest to the fact that Africa was not the land of opportunities that many imagined and the League was looking for solutions in the wrong place. ${ }^{26}$ For the Committee on Raw Materials, the Portuguese government appointed Tomás Fernandes, an economic expert within the Ministry of Foreign Affairs and a former Reparation Commission delegate. The Portuguese strategy became clear during the first meeting in March 1937, as Fernandes tried to convince the committee that the investigation should not be limited to raw materials of colonial origin but instead also include coal, petroleum, iron, copper and other raw materials essential to modern economies that Portugal was compelled to import, even though it was a colonial power. ${ }^{27}$

To understand the Portuguese concern with the League of Nations' enquiry into raw materials, it is necessary to place it within the wider debates on the extension of the mandate system and the creation of alternative forms of international colonial administration. In June 1932 the secretary-general of the Ministry of Foreign Affairs, Luís Teixeira de Sampaio, had already warned of the perils of 'the aspirations of other colonial powers and the propaganda of the idea of internationalisation, which [appears] more or less disguised under the name of cooperation for the African territories'. ${ }^{28}$ As early as September 1930 Teixeira de Sampaio had expressed similar concerns regarding the French minister

in the Prussian-Polish Provinces (1840-1914)', PhD Thesis, University of Michigan, 2010. See also Taras Hunczak, 'Polish Colonial Ambitions in the Inter-War Period', Slavic Review, 26, 4 (1967), 648-56; Piotr Puchalski, 'The Polish Mission to Liberia, 1934-1938: Constructing Poland's Colonial Identity’, The Historical Journal, 60, 4 (2017), 1071-96.

22 Diário de Notícias, 6 Dec. 1937, 1.

23 League of Nations Official Journal. Special Supplement. Records of the Sixteenth Ordinary Session of the Assembly, $1935,45$.

24 'Resolution on an Enquiry into the Question of Equal Commercial Access to Certain Raw Materials', League of Nations Official Journal. Special Supplement. 155. Records of the Seventeenth Ordinary Session of the Assembly, 1936, 141-2.

25 Eugene Staley and K. E. Knorr, Raw-Material Problems and Policies (Geneva: League of Nations, 1946), 58.

26 Speech of the Minister of Foreign Affairs at the Assembly of the League of Nations, 30 Sept. 1936, Doc. 436, in Dez Anos de Política Externa (1936-1947). A Nação Portuguesa e a Segunda Guerra Mundial. Vol. III (Lisbon: Imprensa Nacional, 1964), 378-85.

27 Karl Kapp, Memorandum on the Efforts Made by the League of Nations towards a Solution of the Problem of Raw Materials (Geneva: Geneva Research Center, 1937), 106.

28 'Parecer de Luiz Teixeira de Sampaio', 4 June 1932, ANTT/AOS/CO/UL-12, cx. 805, pt. 1, 1 sub., 2. 
of Foreign Affairs's proposal for the creation of a European Federal Union discussed at the League of Nations. Although Teixeira de Sampaio was not convinced that Aristide Briand's plan would succeed, he was wary of pan-European movements and the possible impact of 'the so-called Europeanisation' of colonial affairs. $^{29}$ It is important to note that Count Coudenhove-Kalergi's International Pan-European Union, which was founded in 1924, had grown in popularity among European elites. Its programme demanded the 'systematic exploration of the European economic colony of West Africa (French Africa, Libya, the Belgian Congo, Angola) as a European resource. ${ }^{30}$ With the intensification of colonial demands in the mid-1930s, anxiety about the International Pan-European Union increased. Elaborating on the minutes of the Fourth Paneuropean Congress's committee on colonial affairs, the Portuguese minister in Vienna concluded that 'this Pan-European Union can only be dangerous as a propaganda vehicle for certain ideas and aspirations'. ${ }^{31}$ But, as an intergovernmental organisation, the League of Nations could take action to put these ideas and aspirations into effect.

In short, the Portuguese government worried not only about the League's enquiry into raw materials in and of itself, but also that it could open a Pandora's box by triggering new investigations and encouraging the discussion on international cooperation in Africa. Their fears turned out to be right. As Susan Pedersen has noted, from 1935 onwards an increasing number of studies called attention to the imbalance of access to colonial raw materials and how this related to the maintenance of peace. ${ }^{32}$ In the United Kingdom, both the National Peace Council's Committee on Economic and Colonial Questions and the British Labour Party's Committee on Imperial Questions favoured the extension of the mandate system and their administration by an international commission, rather than by nations appointed by the League of Nations to administer them on the League's behalf. ${ }^{33}$ This idea was discussed during the Tenth International Studies Conference held by the International Institute of Intellectual Cooperation, in Paris, in the summer of $1937 .{ }^{34}$ Even though the League of Nations' committee concluded that the problem of access to colonial raw materials was one to be solved by the adoption of the Open Door Trade Policy in its final report in September 1937, among the solutions proposed during the first meeting in March was also the transformation of all colonies into mandated territories and the transfer of their administration to an international authority. ${ }^{35}$ In Portugal, such plans were deemed an internationalist or socialist stratagem: while fearing that they could hurt the interests of the Portuguese right-wing dictatorship more than the governments of other nations, it was generally believed that neither British public opinion nor British conservative statesmen would accept such a solution. ${ }^{36}$

29 'Parecer de Luiz Teixeira de Sampaio - Política sobre Plano Briand - Reunião de Genebra 1930', 3 Sept. 1930, Arquivo Histórico-Diplomático do Ministério dos Negócios Estrangeiros (AHD-MNE), Lisbon, S12.1.E15.P4/75510, 2. On the Portuguese reception of Briand Plan, see António Martins da Silva, Portugal e a Europa: distanciamento e reencontro a ideia de Europa e a integração europeia ecos e reacções e posicionamentos (1830-2005) (Viseu: Palimage Editores, 2005), 105-72.

30 Richard Coudenhove-Kalergi, 'Das Pan-Europa-Programm', in Paneuropa, 2 (1924), 4, quoted in Dina Gusejnova, European Elites and Ideas of Empire, 1917-1957 (Cambridge: Cambridge University Press, 2016), 80.

31 José da Costa Carneiro to the minister of Foreign Affairs, 17 July 1935, AHD-MNE, S12.1.E15.P4/75510, 4.

32 Pedersen, Guardians, 341-2.

33 National Peace Council: Advisory Committee on Economic and Colonial Questions (1936), Peace and Colonial Politics, LSE Archives, London, Pamphlet Collection, JC/B107; Labour Party - Advisory Committee on Imperial Questions, The Demand for Colonial Territories and Equality of Economic Opportunity (London: Labour Party, 1936). See also Callahan, A Sacred Trust, 90-4; R. M. Douglas, The Labour Party, Nationalism and Internationalism, 1939-1951 (London: Routledge, 2004), 182.

34 Peaceful Change: Procedures, Population, Raw Materials, Colonies; Proceedings of the Tenth International Studies Conference (Paris, June 28-July 3, 1937) (Paris: International Institute of Intellectual Co-Operation, 1938), 199, 454, $462,473,521$.

35 League of Nations Information Section, Press Communiqué, 8 Mar. 1937, 3-4, quoted in Kapp, Memorandum on the Efforts, 95; compare with Report of the Committee: The Study of the Problem of Raw Materials, Document A.27. II.B. (Geneva: League of Nations, 1937).

36 See, for instance, the Portuguese ambassador's report on the National Peace Council' meeting. R. Ennes Ulrich to minister of Foreign Affairs, 2 Nov. 1935, ANTT/AOS/NE-4C, cx. 377, pt. 2, 19 sub. 
Yet, by January 1938 the Conservative British Prime Minister Neville Chamberlain was convinced that no satisfactory agreement with Germany was possible without some colonial concessions. Chamberlain came up with a plan to address the question of Germany's scarcity of raw materials and overpopulation that would open 'an entirely new chapter in the history of African colonial development'. ${ }^{37}$ His proposal was to carve out a large block in Africa to be administered within an expanded system of international control, in which Germany would participate. The block was to be created by drawing two lines across the continent: the northern line would run roughly to the south of the Sahara, the Anglo-Egyptian Sudan, Ethiopia and Italian Somaliland, and the southern line would run roughly to the south of Portuguese Angola, the Belgian Congo, Tanganyika and Portuguese Mozambique. In short, the portion to be offered to Germany would be mainly comprised of Belgian Congo and Portuguese Angola, while France and the United Kingdom would keep their colonies and mandated territories. ${ }^{38}$ Chamberlain was not the first to suggest settling European powers' demands for colonies by transferring part of the Portuguese colonial empire to the so-called 'have-not' nations. On the contrary, the idea had been in discussion since colonial demands began attracting public attention and interest.

\section{An Anomaly of Modern History: The Portuguese Empire in Question}

On Thursday 23 March 1933 the French newspaper The Paris Echo (L'Écho de Paris) reported that Mussolini had proposed that the Portuguese colonies be divided between Germany and Italy during the Four Power Pact talks with the British Premier, Ramsay MacDonald. ${ }^{39}$ According to this French daily, only as a result of pressure from the British foreign minister had the topic of colonial redistribution been removed from the final text. For the Portuguese Minister Plenipotentiary in Brussels, it was undoubtedly an invention of the press. He argued that the media in the countries that had benefited from the distribution of colonial mandates after the First World War were trying to turn public opinion against Italy; by doing so, they intended to discredit any request for the revision of colonial distribution that Italy might issue in the future. ${ }^{40}$ Yet, at the Portuguese embassy in Rome and in the headquarters of the Ministry of Foreign Affairs in Lisbon the rumours about Italy's interest in the distribution of Portuguese colonies were read with suspicion. ${ }^{41}$

Portuguese diplomats in Italy were convinced that Rome was already building the case for colonial distribution - and was doing so on the back of Portugal. From 1931 onwards unflattering articles about the Portuguese colonies had appeared in Italian colonial propaganda journals, namely in the official The Overseas (L'Oltremare) and the privately-owned The Colonial Action (L'Azione Coloniale). The content of all these articles is strikingly similar. ${ }^{42}$ In a nutshell: the Portuguese had an immense colonial empire that offered essential raw materials and valuable opportunities for European emigration; however, Portugal did not have the necessary capital or people to fulfil its role as a colonising nation and, as a consequence, its neglected colonies remained underdeveloped. Either implicitly or explicitly, the representation of Portuguese colonialism in Italian colonial propaganda journals called attention to the unfairness of the existing colonial partition.

37 'Minutes of Cabinet Committee on Foreign Policy Germany: The Next Steps Towards a General Settlement; The Colonial Question', 24 Jan 1938, Doc. 20 in S. R. Ashton and S. E. Stockwell, eds., Imperial Policy and Colonial Practice, 1925-1945. Part I: Metropolitan Reorganisation, Defence and International Relations, Political Change and Constitutional Reform, vol. 1, British Documents on the End of Empire, A (London: H.M. Stationery Off., 1996), 139.

38 Ibid. See also Louis, 'Colonial Appeasement, 1936-1938'; Crozier, Appeasement, 236-37; Callahan, A Sacred Trust, 13449; Neville, Hitler and Appeasement, 60-76.

39 L'Écho de Paris, 23 Mar. 1933, 1, 3.

40 Alberto d'Oliveira to the minister of Foreign Affairs, 27 Mar. 1933, ANTT/AOS/CO/NE-4A, cx. 375, pt 2.

41 See, for instance, Luís Teixeira de Sampaio's account of his conversation with the Italian ambassador in Lisbon, 29 Mar. 1933, ANTT/AOS/UL-12, cx. 805, pt.2, 2 sub, 10-1.

42 The Ministry of Foreign Affairs sent copies of the translations or summaries of the articles compiled by the Portuguese legation in Rome to the minister of the Colonies. The dossier can be consulted in AHU/MU/DGAPC/1H/1029, Proc. 34A - Penetração Italiana em Angola. 
The Portuguese Minister Plenipotentiary in Poland was also convinced that the Polish government was encouraging a media campaign against Portuguese colonisation. In the early 1930s both private and governmental propaganda initiatives had promoted Angola's natural resources in Poland and encouraged Polish emigration to the Portuguese colony. ${ }^{43}$ After Italy's invasion of Ethiopia, the intensity of colonial propaganda in Poland pushed the Portuguese diplomatic corps to attend a far greater number of conferences and public events in order to assess the potential threat to Portugal's interests. Minister César de Sousa Mendes feared the increasingly aggressive rhetoric and strategy adopted by the Polish Colonial and Maritime League, even though Portugal was not named in the conferences and other public meetings they organised. ${ }^{44}$ However, claims that Portugal was neither experiencing other European powers' economic pressures for colonial possessions nor had the human and material resources necessary to colonise them had become common in the press. ${ }^{45}$ César de Sousa Mendes was also concerned with Polish-Jewish immigration to Portugal and the Portuguese colonies. In July 1936 he had been approached by officers of the Polish Ministry of Foreign Affairs to discuss the establishment of a Jewish territory within Angola's borders. ${ }^{46}$ Plans for the creation of large Jewish settlements in the colony were not unprecedented, having been proposed by both the Universal Israelite Alliance (Alliance Israelite Universelle) in 1886 and the Jewish Territorial Organisation (ITO) in 1910s. ${ }^{47}$ After the Night of Broken Glass (Kristallnacht) in 1938, the idea was revived and Jewish organisations approached the Portuguese government in Lisbon and at the Portuguese embassy in the United Kingdom. Both the minister of the colonies and the ambassador in London shared fears that the Jewish population could not be assimilated and would become an element of disturbance in Angola, which César de Sousa Mendes had already articulated in $1936 .^{48}$

From Berlin, the Portuguese Minister Plenipotentiary did not report the findings of a media campaign against Portuguese colonisation in the press in the same manner as his counterparts in Rome and Warsaw. For Alberto de Veiga Simões it had been clear from the start that Hitler had little interest in colonial expansion to Africa and that German demands for the restitution of the former colonies were a distracting manoeuvre to hide his true aim: 'the restoration of Germaness (Deutschtum) in Europe'. ${ }^{49}$ Nevertheless, an array of rumours regarding Germany's interest in the Portuguese colonies appeared in the international press, especially from 1935 until the outbreak of the Second World War. For instance, in late 1935 the New York Times's correspondent in London wrote that 'there is substantial basis for believing that early in the approaching year Germany will officially demand restoration to

43 Angola's governor to the minister of the Colonies, 26 Jan. 1933, AHU/MU/DGAPC/1H/1029, Proc. 34-A - Penetração Polaca em Angola.

44 César de Sousa Mendes to the minister of Foreign Affairs, 30 Nov. 1936, and 22 Fev. 1938, ANTT/AOS/CO/UL-12, cx. 805 , pt 1, sub. 4 .

45 A set of press clippings and translations, ranging from 1937 to 1939, sent from Warsaw is filed under ANTT/AOS/CO/ UL-12, cx. 805, pt. 1, 4 sub.

46 César de Sousa Mendes to the ministry of Foreign Affairs, 24 July 1936, AHU/MU/DGAPC/1H/1029/ Proc. 34-A Penetração Polaca em Angola.

47 João Medina and Joel Barromi, 'The Jewish Colonization Project in Angola', Studies in Zionism, 12, 1 (1991), 1-16; Ansgar Schäfer, 'Terra Prometida "No Império"?: Os Projectos de Colonização Israelita Em Angola', História, 9 (1995), 32-45; Ansgar Schäfer, 'Angola, Terra Prometida?', História, 14 (1995), 52-64.

48 On the proposals for the establishment of large-scale Jewish settlement on the eve of the Second World War and its reception in Portugal, see Ansgar Schäfer, Portugal e Os Refugiados Judeus Provenientes Do Território Alemão (1933-1940) (Coimbra: Imprensa da Universidade de Coimbra, 2014), 153-65. It is worth noting that the Ministry of Foreign Affairs had been intensifying efforts to prevent the immigration of Jewish people to the metropole since 1933. On the evolution of the New State regime's rhetoric regarding Jewish people and other 'undesirable' migrants, see Susana Chalante, 'O Discurso Do Estado Salazarista Perante o "Indesejável” (1933-1939)', Análise Social, XLVI, 198 (2011), 41-63.

49 Veiga Simões to the minister of Foreign Affairs, 18 Nov. 1935, in Lina Alves Madeira, ed., Correspondência de um diplomata no III Reich: Veiga Simões ministro acreditado em Berlim de 1933 a 1940 (Coimbra: Mar da Palavra, 2005), 75. Veiga Simões headed the Portuguese diplomatic mission in Berlin from 1933 to 1940, keeping a very critical view on the German regime and a remarkable grasp of Hitler's intents. See Lina Alves Madeira, Alberto da Veiga Simões: esboço biográfico (Coimbra: Quarteto, 2002). 
the galaxy of colonial powers'. He then went on to state that, according to rumour, the Portuguese colonies would be - in whole or in part - transferred to Germany, since Portugal had already agreed with the United Kingdom to renounce its rights over the territories. ${ }^{50}$ As late as 1939 Salazar was still asking the Portuguese Minister Plenipotentiary in Washington to make sure that President Roosevelt did not believe the rumours suggesting that Portugal would accept ceding any of its colonies. ${ }^{51}$ Among the many examples of such rumours ${ }^{52}$ was the news that Joachim von Ribbentrop, the German ambassador at large in London, and Prime Minister Stanley Baldwin had discussed the transfer of Angola and Mozambique on the occasion of the signature of the Anglo-German Naval Agreement in June $1935 .{ }^{53}$ In addition, the Union of South Africa's minister of Defence, Oswald Pirow's, autumn 1938 European tour gave rise to yet more rumours. Known for his pro-Germanism and his stance against the return of German South West Africa (now a mandate administered by the Union of South Africa as an integral portion of its territory), Pirow stopped in Lisbon before visiting London and Berlin, which the international press described as a mission to negotiate a transfer of Angola to Germany with the Portuguese Government. ${ }^{54}$

Lord Halifax's trip to Berlin in 1937 also riled up the international press. The British press argued that Hitler would not abandon Germany's demand for the return of its former colonies in West Africa (Togo and Cameroon) but was willing to consider ceding its claims to Tanganyika in exchange for a reasonable compensation comprised of a block containing parts of the Belgian Congo and Angola to be administered as a League of Nations' mandate. According to The Evening Standard this idea had not been presented to Halifax by Hitler himself but instead by the president of the Reichsbank, Hjalmar Schacht. ${ }^{55}$ Based on Halifax's account presented during a meeting with British and French officials in London, the rumour was true. ${ }^{56}$ The British Foreign Office was already aware that Schacht thought that what Germany really needed was a territory like Angola, if it could in fact be acquired from Portugal. ${ }^{57}$ But Schacht had earned a firm international reputation as an advocate of German colonial needs in public circles, too, claiming that returning colonies was essential for solving Germany's problem of access to crucial supplies of raw materials and fresh markets for its industries. In this regard it is worth noting his article in Foreign Affairs in January 1937, especially its alarming conclusion: 'the German colonial problem is not a problem of imperialism. It is not a mere problem of prestige. It is simply and solely a problem of economic existence. Precisely for that reason the future of European peace depends upon it. ${ }^{58}$

It is also worth noting that the same Foreign Affairs issue included an article entitled 'The Future of Portugal's Colonies'. For its author, Robert Gale Woolbert, 'one of the anomalies of modern history is

50 The New York Times, 30 Dec. 1935, 1.

51 Salazar to João António de Bianchi, 4 Apr. 1939 (Doc. 598), Dez Anos de Política Externa (1936-1947). A Nação Portuguesa e a Segunda Guerra Mundial. Vol. II (Lisbon: Imprensa Nacional, 1973), 233-4. Roosevelt was convinced that the creation of a Jewish homeland was an essential step for the solution of the Jewish refugee problem and believed that Angola offered the most favourable facilities for its creation. See the telegram from the US Secretary of State, Cordell Hull, to the Ambassador in the United Kingdom, 14 Jan. 1939 (Doc. 48), Foreign Relations of the United States: Diplomatic Papers, 1939. Volume II, General - The British Commonwealth and Europe. (Washington, DC, Government Printing Office, 1956), 66-9.

52 It was not possible to track them all. References in both Portuguese diplomatic records and the national contemporary press are not always precise, lacking concrete date and/or publication's title.

53 L'Écho de Paris, 22 June 1935, 3; Le Temps, 22 June 1935, 1. Ribbentrop had become closely involved in the politics of the colonial revisionism movement in Germany. See Crozier, Appeasement, 137-8.

54 Deputy Chief of Portuguese Mission in Pretoria to Salazar, 25 Oct. 1938 (Doc. 423) and 27 Oct 1938 (Doc. 433 ); Portuguese ambassador in London to Salazar, 26 Oct. 1938 (Doc. 424) in Dez Anos de Política Externa. Vol. II, 30, $31,40$.

55 The Evening Standard, 1 Dec. 1937, 1

56 See the Records of Cabinet Committees, Minute 10, 6 Dec. 1937, TNA/CAB 27/626.

57 According to the report of a conversation between Schacht and The Times's correspondent in Berlin to the British ambassador in Germany, A.L. Kennedy to Sir Eric Phipps, 25 May 1936, TNA/FO 371/19927, C3906/97/18.

58 Hjalmar Schacht, 'Germany's Colonial Demands', Foreign Affairs, 15, 2 (1937), 223-34. See also Crozier, Appeasement, 169-206. 
the survival of Portugal as an important colonial Power'. ${ }^{59}$ He went on to point out that 'Portugal lacks the capital, the man power and the energy to develop her colonies'. He concluded that it would be difficult for Portugal to 'prove that she herself needs or is able to fully utilise the resources of her extensive colonial domain' should a redistribution of African colonies take place in the future. ${ }^{60}$ In many respects this article, authored by Woolbert, an American Professor of History, and published in the magazine of an influential internationalist institution like the Council on Foreign Relations, resembles the articles found in Italian and Polish magazines or newspapers at the time their authoritarian governments were putting forward their demand for colonies.

This is an important point. The international debate on the fairness of colonial distribution and the necessity of rebalancing the allocation of colonial resources in the modern world and the international examination of Portuguese colonialism were two strands of the same discussion; moreover, the latter was crucial for legitimising the former. In exposing Portugal's limitations these debates did not merely expose the inadequacy of available material resources and people to colonise vast overseas territories, they also exposed the inadequacy of the Portuguese colonial practices, which were not appropriate to the modern world. As the British Daily Express explained to its readers, the Portuguese had learned little about colonisation during its many centuries as a colonial power: in Portuguese Africa, the standard of living was so low that Africans would benefit from being ruled by anyone other than the Portuguese. $^{61}$

The League of Nations, as Mark Mazower has noted, made a major contribution to redefining Europe's relations with the colonial world after the First World War: even though colonial powers rejected their colonies' self-determination, carrying on with colonial rule along nineteenth-century lines had become unacceptable to the international public. ${ }^{62}$ Despite the colonial powers' strong opposition, the principle of international scrutiny and accountability introduced by the League and, in particular, by its Permanent Mandates Commission - had changed the way imperial affairs were discussed in the interwar period. The civilising mission was no longer exclusively a concern of the colonising nations but instead part of an international programme of tutelage that transcended national boundaries and had been brought into public consciousness. ${ }^{63}$ The Permanent Mandates Commission had been created to supervise the mandatory powers' administration, but it became a space for a broader discussion and comparison of different systems of colonial administration. In short, it became the forum through which the terms of good colonising practices, as well as the methods to adopt them beyond the mandatory system, were defined. ${ }^{64}$ Portugal's colonising practices were not in compliance with the accepted standards of good colonial governance. The Portuguese had earned a bad reputation as colonisers within the League of Nations' bodies, in particular regarding the labour conditions that were being offered to Africans in the Portuguese colonial territories. The discussions on 'native' labour in the Portuguese Empire at the League's Temporary Slavery Commission and during the International Labour Organisation's work sessions for the Forced Labour Convention had been followed and reported on by the international press, reviving and reinforcing the negative image left by the highly publicised Portuguese 'slave cocoa' controversy in

\footnotetext{
59 Robert Gale Woolbert, 'The Future of Portugal's Colonies', Foreign Affairs, 15, 2 (1937), 374.

60 Woolbert, 'Future', 379.

61 Daily Express, July 1937, quoted in Leite de Magalhães, 'Corso de Salão', O Mundo Português, 48 (1937), 561-6.

62 Mark Mazower, Governing the World: The History of an Idea (New York: Penguin, 2012), 166.

63 Véronique Dimier, 'L'internationalisation du débat colonial: rivalités autour de la Commission permanente des Mandats', Outre-Mers. Revue d'histoire, 89, 336 (2002), 333-60; R. M. Douglas, Michael Dennis Callahan and Elizabeth Bishop, eds., Imperialism on Trial: International Oversight of Colonial Rule in Historical Perspective (Lanham, MD: Lexington Books, 2006); Vernon Hewitt, 'Empire, International Development \& the Concept of Good Government', in Mark Duffield and Vernon Hewitt, eds., Empire, Development \& Colonialism: The Past in the Present (Suffolk: James Currey, 2013), 30-44; Pedersen, Guardians; Miguel Bandeira Jerónimo, 'A League of Empires: Imperial Political Imagination and Interwar Internationalisms', in Miguel Bandeira Jerónimo and José Pedro Monteiro, eds., Internationalism, Imperialism and the Formation of the Contemporary World: The Pasts of the Present (Basingstoke: Palgrave Macmillan, 2018), 87-126.

64 Veronique Dimier, 'On Good Colonial Government: Lessons from the League of Nations', Global Society, 18, 3 (2004), 279-99.
} 
the first decade of the twentieth century, as the 'blood rubber' scandal had done to the Congo Free State under Leopold II. ${ }^{65}$

The League of Nations implemented the principle of international scrutiny and accountability of imperial affairs and fomented their discussion with international public opinion. By doing so the League ended up providing the means to make colonial appeasement plans look acceptable to many. First, it offered a new political language of colonial internationalism in which national interests could be reframed as supra-national ones and the transfer of territory from a colonial power to another could be retooled as a shared trust of civilisation. Moreover, the international scrutiny of good versus bad colonial governance provided additional legitimacy to plans of redistributing colonial territories, underpinning a narrative of the rescue of the colonies and their backward peoples from the hands of colonial powers that were not perceived as capable of fulfilling their mission.

\section{The Portuguese Nationalist Response}

While they were unable to put an end to the rumours about the Portuguese empire circulating in the international media, Portuguese diplomatic representatives urged foreign governments to take measures to deny them and to control the newspapers that spread them. ${ }^{66}$ However, in Portugal a censored and state controlled press - including titles published by the official colonial propaganda agency itself - amplified these same rumours, fuelling a heated conversation about international attacks on the Portuguese Empire's integrity. To understand this paradox it is important to keep in mind that, while the international consequences of a future redistribution of colonial territories to satisfy Germany's colonial demands were a matter of concern, at home the discussion of colonial appeasement plans represented an unrivalled opportunity for bolstering the regime's authoritarian nationalism. It is possible to identify three main ways in which colonial appeasement was exploited for domestic purposes in Portugal: to promote national unity in face of a foreign threat, to praise the Portuguese dictatorship and to highlight the divide between Portugal and the other European colonial powers.

First, the uproar in the national press caused by references to the existence of international proposals for the 'robbery' or 'despoil' of the Portuguese empire aimed to generate internal cohesion against a perceived external enemy. Even though it was stressed that the foreign rumours were completely unfounded and the United Kingdom would not disrespect its alliance with Portugal, they were often placed in the wider context of a dangerous internationalisation of colonial affairs that dated back to the Berlin Conference of $1884-5 .{ }^{67}$ The argument was that the scramble for Africa had never ended and that historically Portugal had been the main victim of actual and attempted crooked schemes. In addition to the Berlin Conference, in which Portuguese historical claims based on priority of discovery and travel in the Congo had been dashed, Anglo-German negotiations for the partition of

65 On the discussions of 'native' labour in the Portuguese Empire, see Kevin Grant, A Civilised Savagery: Britain and the New Slaveries in Africa, 1884-1926 (New York: Routledge, 2005), 104-34; Miguel Bandeira Jerónimo, Livros brancos, almas negras: a 'missão civilizadora' do colonialismo português, c. 1870-1930 (Lisbon: Imprensa de Ciências Sociais, 2010), 211-50; Miguel Bandeira Jerónimo and José Pedro Monteiro, 'Internationalism and Empire: The Question of Native Labour in the Portuguese Empire, 1924-1962', in Simon Jackson and Alanna O'Malley, eds., The Institution of International Order: From the League of Nations to the United Nations (New York: Routledge, 2018), 206-33. For a comprehensive overview on the question of slavery and 'native' labour in the League of Nations and ILO, see Suzanne Miers, Slavery in the Twentieth Century: The Evolution of a Global Problem (Walnut Creek, CA: AltaMira Press, 2003), 100-73; Luis Rodríguez-Piñero, Indigenous Peoples, Postcolonialism, and International Law: The ILO Regime (1919-1989) (Oxford: Oxford University Press, 2005), 17-52.

66 See, for instance, Armindo Monteiro to Salazar, 28 Oct. 1938 (Doc. 442); Ferreira da Fonseca to Salazar, 5 Nov. 1938 (Doc. 461), Dez Anos de Política Externa. Vol. II, 48-50, 70-1.

67 The best study on the unfolding of events with regard to the scramble for Africa that does not overlook the Portuguese experience remains H. L. Wesseling, Divide and Rule: The Partition of Africa, 1880-1914 (London: Praeger, 1996). See also Valentim Alexandre, 'Nação e Império', in Francisco Bethencourt and Kirti Chaudri, eds., História Da Expansão Portuguesa, vol. IV (Lisbon: Círculo de Leitores, 1998), 90-142. 
Portuguese colonial possessions in 1898 and 1912 were also remembered in order to reinforce a rhetoric of victimisation. ${ }^{68}$ Although these conventions were secret, the posthumous publication of the German minister of Foreign Affairs, Prince von Bülow's, memoirs in 1898 had confirmed their existence in the early 1930s. ${ }^{69}$ Repeated references to past Anglo-German negotiations seemed to be at odds with the vehement denial of current British colonial appeasement intentions: if the United Kingdom had betrayed its oldest ally in the past, why would it be any different this time? The answer lies in a second function served by colonial appeasement rumours.

Rumours about the Portuguese colonies were also a golden opportunity to express approval and admiration for Salazar's policies. For once they were used to justify the need to control the press, equating free media with fake news and thus legitimising censorship in order to protect public opinion. But, more importantly, they were used to rave about Salazar's success in balancing the national budget through the adoption of strict austerity policies. Salazar had targeted the longstanding Portuguese national debt as soon as he took office as Minister of Finance in 1928, quickly being lauded as 'the saviour of Portugal' by admirers both in Portugal and abroad. ${ }^{70}$ This narrative became especially useful with the appearance of rumours about colonial distribution. The Anglo-German agreements in both 1898 and 1912 had as conditions that the two countries would aid Portugal financially and that its colonies would serve as a guarantee for loans that Portugal would most likely fail to pay back. $^{71}$ Already in 1931 Salazar had publicly made references to Bülow's Memoirs, using the AngloGerman negotiations over the Portuguese colonies as a reminder of how the Portuguese financial crisis during the parliamentary regimes that preceded the military coup had been used abroad to legitimise 'spoliation plans'.

Finally, the third domestic use of the rumours was to emphasise the divide between Portugal and the other colonial powers, revisiting myths of Portuguese exceptionalism. The crucial point of differentiation that was repeated in the national press was that, unlike the other colonial powers, Portugal had not 'discovered colonies quietly in the offices of [their] chancelleries'. ${ }^{73}$ Instead, Portugal's colonial empire had been heroically discovered and conquered - the result of a five-centuries-long collective effort of the Portuguese people -, and the empires of the other European states could not have been constructed without Portugal's earlier achievements. ${ }^{74}$ While the 'new' European colonial nations were driven by a desire for economic gains, the Portuguese empire, it was argued in the national press, was a sacred heritage and colonisation had become an inherent part of the Portuguese national spirit. ${ }^{75}$ As a result, Portugal could not accept compensation for any part of its empire: the colonies and the metropole had become one. In the words of the Portuguese minister of the Colonies in a 1935 interview, 'our colonies, as our metropolitan provinces, form a whole: they are the Portuguese overseas provinces'.

68 Victimisation was not unique to the Portuguese rhetoric. Claims of victimhood were central to revisionist narratives about the German 'colonial guilt lie' and Italian 'mutilated victory'. See, for instance, Wempe, Revenants; Burgwyn, The Legend of the Mutilated Victory. Victimisation also pervaded Polish complaints about the unfairness of a colonial order that resulted from the partition of Africa, in which Poland had been unable to take part because it was under a foreign rule at the time. Hunczak, 'Polish Colonial Ambitions'.

69 The English translation published by Putman in 1931 garnered media coverage in Portugal. See A Voz, 5 Mar. $1931,1$.

70 On the importance of Salazar's accomplishment for his political ascension, see Helena Matos, Salazar. Vol. 1. A Construção do Mito, 1928-1933 (Lisbon: Temas e Debates, 2003). On Salazar's international recognition, see Filipe Ribeiro de Meneses, Salazar: A Political Biography (New York: Enigma Books, 2010), 46-53.

71 José de Almada, Convenções anglo-alemãs relativas às colónias portuguesas (Lisbon: Estado-Maior do Exército, 1946); Richard Langhorne, 'Anglo-German Negotiations Concerning the Future of the Portuguese Colonies, 1911-1914', The Historical Journal, 16, 2 (1973), 361-87. See also Rolf Peter Tschapek, Bausteine eines zukünftigen deutschen Mittelafrika: deutscher Imperialismus und die portugiesischen Kolonien (Stuttgart: Franz Steiner, 2000).

72 António de Oliveira Salazar, 'O Interesse Nacional Na Política Da Ditadura (17 de Maio de 1931)', in Discursos. I. 1928 1934 (Coimbra: Coimbra Editora, 1948), 122-4.

73 Diário de Notícias, 29 Mar. 1933, 1.

74 Ibid., 22 Aug. 1935, 1.

75 See, for instance, Augusto Cunha, 'Crónica colonial', Boletim Geral das Colónias, XIV, 152 (Feb. 1938 ), 69.

76 Diário de Notícias, 27 July 1938, 1. 
To be sure, even though claims that Portugal had overseas provinces rather than colonies appeared often in the reactions to the rumours about the redistribution of Portuguese colonies, there was no formal change in their designation until the 1951 constitutional revision. Moreover, it is important to note that the ideas associated with the myth of Portuguese exceptionalism were not born in Salazar's dictatorship, let alone as a response to colonial appeasement rumours. ${ }^{77}$ Pre-existing discourses of national identity understood in terms of empire were appropriated and consolidated during the regime, being at the heart of its nationalist discourse; ${ }^{78}$ by keeping imperial nationalism on the first pages of the mainstream press, the rumours helped popularise it. It was in the context of the proliferation of rumours about the Portuguese colonies that a Portuguese chief of state made an official visit to Portuguese Africa for the first time. President Carmona's tours to Angola and São Tomé and Principe in 1938, as well as to Cape Verde and Mozambique the following year, were converted into major propaganda events to bolster the bonds of empire and affirm Portuguese sovereignty over the colonies. The presidential voyage, as stated in the official announcement in 1938, 'represents the principle of national unity that has always informed our overseas action'. ${ }^{79}$

Furthermore, the proliferation of news about the redistribution of African colonies triggered debates on the need to intensify Portuguese settlement and investment in order to counter allegations that Portugal did not have the human and financial resources necessary to remain among the colonial powers of the twentieth century. ${ }^{80}$ A noteworthy example of this renewed interest was the organisation of the First Economic Conference of the Portuguese Colonial Empire, a governmental initiative that took place in Lisbon in June $1936 .{ }^{81}$ In the previous year the new law for national economic reconstitution had stressed the importance of colonial development as a key element for the new Portuguese economic policy, alongside national security and metropolitan infrastructural development. ${ }^{82}$ While significant developmentalist policies designed for the colonies only took place after the Second World War, timid colonial development plans were devised for Mozambique and Angola in 1937 and 1938, respectively. ${ }^{83}$

\section{Conclusion}

Germany rejected the offer to administer an African colony within an expanded system of international control and hence Chamberlain's 1938 plan never moved beyond the realm of ideas. To fully understand an idea, we must situate it within the circumstances of its production, not overlooking what its author intended to accomplish. The motivation of statesmen and intellectuals that discussed, either in public or in the secrecy of cabinet/intergovernmental meetings, the transfer of a piece of Africa to Germany was very obvious: despite having invoked the Germans' brutality against Africans to force Germany to forfeit all of its colonial possessions back in 1919, 'colonial appeasers'

77 For an overview of imperial nationalism before the dictatorship, see Alexandre, 'Nação e Império'.

78 Paulo Polanah, 'An Imperial Mystique: Colonial Discourse and National Identity in Portugal 1930-1945', Portuguese Studies Review, 16, 1 (2008).

79 Diário de Notícias, 19 Mar. 1938, 1

80 See, for instance, Cláudia Castelo, Passagens Para África: O Povoamento de Angola e Moçambique Com Naturais Da Metrópole (1920-1974) (Porto: Afrontamento, 2007), 61-106; Cláudia Castelo, 'Developing "Portuguese Africa" in Late Colonialism: Confronting Discourses', in Joseph Hodge, Gerald Hödi and Martina Kopf, eds., Developing Africa: Concepts and Practices in Twentieth-Century Colonialism (Manchester: Manchester University Press, 2014), 63-86; Miguel Bandeira Jerónimo and António Costa Pinto, 'A Modernizing Empire? Politics, Culture and Economy in Portuguese Late Colonialism', in Miguel Bandeira Jerónimo and António Costa Pinto, eds., The Ends of European Colonial Empires: Cases and Comparisons (Basingstoke: Palgrave Macmillan, 2015), 51-80.

81 Primeira Conferência Económica Do Império Colonial Português. Pareceres, Projectos de Decreto e Votos, 2 vols (Lisbon: Ministério das Colónias, 1936).

82 Decree-Law 1914, Diário do Governo, 24 May 1935.

83 On post-war development plans, see Victor Pereira, 'A Economia Do Império e Os Planos de Fomento', in Miguel Bandeira Jerónimo, ed., O Império Colonial Em Questão, Sécs. XIX-XX: Poderes, Saberes e Instituições (Lisbon: Edições 70, 2013), 251-85; Jerónimo and Pinto, 'A Modernizing Empire?'. 
wanted to preserve peace in Europe. Literature on colonial appeasement has also made clear why neither the United Kingdom nor France were willing to return any of the former German colonies and instead looked for an alternative solution, mainly at the expense of Belgium's and Portugal's colonial empires. What approaches that favour an analysis of colonial appeasement from the great powers' perspective have failed to address is how the idea had become legitimate in an international context that espoused guarantees of political independence and territorial integrity to great and small states alike.

By shifting our gaze away from the great powers, this article has shown that Chamberlain's plan arose out of a context of existing discussion and debate that normalised handling over the Portuguese possessions to another power. Throughout the 1930s there was a pervasive image in which Portugal stood apart from the other colonial powers, not only due to its lack of resources for developing and occupying their vast African possessions but also because of its old-fashioned methods in dealing with colonised peoples and in administrating the colonial territories. In a context of aggravated European rivalries and claims for access to colonial resources, that image made it possible to couch the idea of appeasing Germany at the expense of the Portuguese empire in a language of modernity, progress and ethical superiority. In short, as Salazar rightly feared, the rumours about the Portuguese colonies prepared international public opinion to accept 'solutions that would have been inadmissible in other circumstances'. ${ }^{84}$

Moreover, by looking at the movement for colonial appeasement from the viewpoint of a 'marginal' European power like Portugal and moving beyond the diplomatic records of the great powers, this article has challenged the view that this movement had little impact. Even though plans for redistribution of the African colonies were not implemented in the 1930s, the fear that it would take place and affect the Portuguese empire energised not only debates on colonial administration in Portugal but also an ardent rhetoric that fostered an imperially constituted notion of national identity. In this rhetoric, too, there was a pervasive image in which Portugal stood apart from the other colonial powers: alone, against the modern 'piracy in tails and white gloves' of the scramble for Africa, now reloaded with the respectable interwar language of internationalism. ${ }^{85}$

Acknowledgments. This article builds on a chapter of my doctoral thesis funded by the Portuguese Foundation for Science and Technology (Grant SFRH/BD/60340/2009) and the Portuguese Ministry of Foreign Affairs and supervised by Professor Sebastian Conrad and Dr Miguel Bandeira Jerónimo. Christoph Kalter's precious suggestions on a preliminary version of this text were crucial to developing my argument. I would also like to thank the Contemporary European History editorial team and the three anonymous reviewers for their comments and feedback. A final mention is due to Diana Anselmo and Samuël Coghe, who kindly put their home institutions' excellent library resources at my disposal while I was writing this article.

\footnotetext{
84 Salazar to Armindo Monteiro, 9 Dec. 1938 (Doc. 504), Dez Anos de Política Externa. Vol. II, 116.

85 Leite de Magalhães, 'Piratas antigos e modernos', O Mundo Português, 47 (1937), 499.
}

Cite this article: Gonçalves M (2021). The Scramble for Africa Reloaded? Portugal, European Colonial Claims and the Distribution of Colonies in the 1930s. Contemporary European History 30, 2-15. https://doi.org/10.1017/S0960777320000314 